\title{
Taxation of investments into ecological innovations in Russia
}

\author{
Galina Semenova ${ }^{1,2, *}$ \\ ${ }^{1}$ Moscow Region State University, 105005, Radio str, 10A, Moscow, Russia \\ ${ }^{2}$ Plekhanov Russian University of Economics, 117997, Stremyanny lane 36, Moscow, Russia
}

\begin{abstract}
The problems of the enterprises' investments into ecological innovations for saving the natural resources are considered in the article. The conditions and factors influencing introduction of ecological innovations in the sphere of economy of Russia are described. The dynamics of the share of the enterprises performing ecological innovations in the total quantity of the enterprises which had completed their innovations is systematized, as well as the dynamics of the special costs connected with ecological innovations. Though the legislation offers some special tax benefits for the enterprises performing their research and development connected with the ecological innovations, problems still exist. The author proves that the implementation of the technologies developed by such "preferential" research and development does not make much profit for the producer of innovations; a little share of the enterprises performing ecological innovations is also revealed. Comparative, economical and statistical methods of the analysis were used for the justification of the authors conclusions. The achieved results of the research can be used in the sphere of forming of regional innovation policy, in the sphere of the development of the standard legal framework of stimulation of ecological innovations in the economy of Russia and other countries.
\end{abstract}

\section{Introduction}

Investments into innovations are developed poorly in Russia. It is the result of the lack of financing source, investment is mostly carried out at the expense of own funds of business. After the collapse of the USSR many design bureaus, research centres were closed that led to the decline of creation of innovations in the country. Now in Russia, the share of innovative activity makes only $1 \%$. Comparing to other developed countries, innovative activity there makes up from 10 to 30 in \% of all the production. The share of innovatively active enterprises in the total number of the industrial enterprises is the following: in Russia - 9.3\%, in Ireland - 75\%, in Canada - 67\%, in Germany - 66\%, in Australia - $60 \%$, in Belgium - 59\%, in the Netherlands - 55\%, in Iceland - 54\%, in Austria - 53\%, in Finland $49 \%$, in France - 46\%, in Great Britain - 39\% [1].

\footnotetext{
* Corresponding author: Sg6457@mail.ru
} 
Innovation is the final result of investment activities, which received the embodiment in the form of a new or advanced product, introduced in domestic or foreign market; a new or advanced technological process used in practical activities or a new approach to social services - that is the essence of innovations in environmental management as the bases of economic growth and maintenance of favourable conditions for the accommodation and activity of the person.

There is a lot of reasons of environmental pollution, the human factor is not always fault to it. Most of all natural cataclysms break harm to clean reservoirs. But industrial and household sewage are considered as the most widespread sources of pollution of water. Water, which did not pass the cleaning system and was not cleared of chemical harmful substances, provokes environmental disaster when getting to a reservoir. All the industrial exhaust gases, exhausts of cars, having got to the atmosphere, come back with the rain to the earth, water reservoirs. Therefore there are acid rains. Solid waste and garbage do not just pollute the rivers, but they even change the current course, there are floods of lakes and rivers. Natural decomposition (dying off of plants, animals) causes organic pollution. Industrial accidents, thermal, radiation pollution, mud flows, avalanches occurs due to the technogenic catastrophes.

\section{Materials and Methods}

A great problem in the sphere of environmental protection is in many respects connected with the environmental policy of Russia. It is possible to name such a shortcoming of Russian policy as the lack of ecological priorities in economic strategy, including the shortage of accurately formulated strategy in nature protection area, problems in the legislative sphere, low level of financing of nature protection actions, low level of attention of the population to ecological culture, in nature protection area weak innovative activity. Ecological innovations are shown in Table 1, it is especially possible to allocate extremely low special costs, connected with ecological innovations with the use of computer facilities and information technologies, research and development which makes up only $0.5 \mathrm{bln}$. roubles and did not increase during three years.

Up to $100 \mathrm{bln}$. ton of ore, natural fuel and resources, which are spent on various production materials is extracted from a subsoil of the planet annually. Natural gas and oil production makes up to $5 \mathrm{bln}$ tons in a year. Every year more than $200 \mathrm{mln}$. ton of carbon oxide and approximately $150 \mathrm{mln}$. tons of sulfur dioxide is released into the atmosphere by the industrial enterprises. About $10 \mathrm{mln}$. tons of oil annually are merged to the World Ocean by negligence or purposely. The areas of soils, suitable for agriculture has decreased by $67 \mathrm{mln}$. ga. All this breaks natural balance of the nature and causes an overload for ecosystems, that is irreversibly leads to the pernicious processes, happening in the environment [6].

Why are not the enterprises actively engaged in ecological innovations? What is better: to pollute the environment with wastes, to burn garbage, to merge the fulfilled material to the rivers? If they do not possess necessary resources or cannot carry out the research and development, it is possible to get developments of other enterprises, and the existence of ecological taxes has to stimulate the implementation of the most modern scientific technologies [3]. In many countries there are different innovative politicians, their forms of realization are various, for example, support of institutes, universities and researchers, tax benefits on investments into research and development, on income from innovations to natural persons, the mode of protection of intellectual property rights, etc. 
Table 1. Ecological innovations [4].

\begin{tabular}{|c|c|c|c|}
\hline $\begin{array}{l}\text { Specific weight of the organizations, which were carrying out } \\
\text { ecological innovations, in the total number of the organizations, } \\
\text { which had complete innovations within the last three years, \% }\end{array}$ & 12.9 & 13.6 & 14.0 \\
\hline $\begin{array}{c}\text { extracting, processing productions, production and } \\
\text { distribution of power, gas and water }\end{array}$ & 15.3 & 16.0 & 16.6 \\
\hline $\begin{array}{l}\text { communication, activity connected with the use of } \\
\text { computer devices and information technologies, research } \\
\text { and development, providing other types of services }\end{array}$ & 8.3 & 9.0 & 9.6 \\
\hline $\begin{array}{l}\text { Special expenses connected with ecological innovations, } \\
\text { bln roubles. }\end{array}$ & 15.1 & 20.9 & 22.0 \\
\hline $\begin{array}{l}\text { extracting, processing productions, production and } \\
\text { distribution of power, gas and water }\end{array}$ & 1.6 & 20.4 & 21.5 \\
\hline $\begin{array}{l}\text { communication, activity connected with use of computer } \\
\text { devices and information technologies, research and } \\
\text { development, providing other types of services }\end{array}$ & 0.5 & 0.5 & 0.5 \\
\hline $\begin{array}{l}\text { Specific weight of the organizations, using the control system } \\
\text { for environmental pollution, in the total number of the surveyed } \\
\text { organizations, \% }\end{array}$ & 10.8 & 11.1 & 10.6 \\
\hline $\begin{array}{l}\text { extracting, processing productions, production and } \\
\text { distribution of power, gas and water }\end{array}$ & 15.4 & 16.2 & 16.4 \\
\hline $\begin{array}{l}\text { communication, activity connected with use of computer } \\
\text { devices and information technologies, research and } \\
\text { development, providing other types of services }\end{array}$ & 3.9 & 3.8 & 3.4 \\
\hline
\end{tabular}

*Starting with the report for 2016, statistical information is developed once in two years, for odd years.

In Russia there are such forms of tax benefits for the enterprises, which are engaged in innovations, too. For example, when determining tax base on income tax, the income gained by the enterprise in the form of property within target financing; income in the form of the means which arrived on formation of funds of support of scientific, scientific and technical, innovative activity are not considered. It is possible to use the accelerated depreciation to the main norm with application of special coefficient:

- for the depreciable fixed assets relating to the facilities having high power efficiency or to the facilities having a high class of power efficiency not higher than 2;

- for the depreciable fixed assets used only for the implementation of scientific and technical activity not higher than 3 .

That allows the enterprises to increase their expenses, thereby reducing their taxable profit, and to pay less tax on profit [2].

It is possible to use the investment tax credit, i.e. the change of term of payment of the tax, during a certain term and in certain limits to reduce the profit tax payments, regional and local taxes payments with the subsequent stage-by-stage payment of the sum of the credit and the added percent for a period from one year up to five years.

The investment credit is granted by tax authority in the presence if at least one of the following circumstance exists: carrying out research or developmental works by the organization, or modernization of own production including directed to creation of jobs for disabled people or increase in power efficiency of goods production, performance of work, rendering services, or implementation of an action or actions for the decrease in negative impact on the environment; implementation of implementation or innovative activity, including creation new or improvement of the applied technologies, creation of new types of raw materials or materials; implementation of investments into creation of the objects having the highest class of power efficiency. Reduction of the tax is made on each payment of the corresponding tax, for each reporting period until the sum, which is not paid by the 
organization as the result of all such reductions (the saved-up credit sum), does not become the equal sum of the credit, provided by the relevant contract. It allows the enterprises to pay less taxes, i.e. with the subsequent delay.

\section{Results}

Tax burden on income tax is specified as follows:

$$
T B_{i}=\frac{T_{i}}{\left(I_{r}+E_{c h}\right)}
$$

where, $\mathrm{TB}_{\mathrm{i}}-$ tax burden on income tax;

$\mathrm{T}_{\mathrm{i}}$ - the income tax, accrued to payment according to the declaration;

$\mathrm{I}_{\mathrm{r}}$ - income from the realization, determined according to the profit declaration;

$\mathrm{E}_{\mathrm{ch}}$ - extraordinary charge determined according to the declaration by profit.

The value added tax (VAT) is an indirect tax, which is joined to the price of goods, works and services and is paid by the consumer.

It is possible to calculate the VAT burden in several ways:

The first way:

$$
\text { TBvat }=\frac{T_{v a t}}{T B_{r f}}
$$

where, $\mathrm{TB}_{\mathrm{vat}}$ - VAT burden;

$\mathrm{T}_{\mathrm{vat}}$ - VAT, added to payment according to the declaration;

$\mathrm{TB}_{\mathrm{rf}}$ - tax base, determined according to Section 3 of the VAT declaration (the market of the Russian Federation).

The second way:

$$
T B v a t=\frac{T_{v a t}}{T B_{g e n}}
$$

where, $\mathrm{TB}_{\mathrm{vat}}-\mathrm{VAT}$ burden;

$\mathrm{T}_{\mathrm{vat}}$ - VAT, added to payment according to the declaration;

$\mathrm{TB}_{\mathrm{gen}}$ - tax base determined as the sum of the tax bases reflected in Sections 3 and 4 of the VAT declaration (the market of the Russian Federation plus export).

If the organizations carry out research and development, relating to the creation of new products and technologies or to the improvement of the made products and technologies, then such performance is exempted from VAT. At the same time this privilege is applied in case if the structure of research, developmental and technological works joins the following types of activity: development of a structure of an engineering facility or technical system; development of new technologies, that is the ways of association of physical, chemical, technological and other processes with labour processes in the complete system making new products (goods, works, services); creation skilled, that is not having the certificate of conformity, samples of the cars, the equipment, materials having basic features, characteristic of innovations, and not intended for realization to the third parties, their test during the time necessary for data acquisition, accumulation of experience and their reflection in technical documentation.

Cumulative tax burden is estimated as follows:

$$
T B=\frac{\mathrm{T}_{y} * 100 \%}{S R_{y}-\mathrm{VAT}}
$$

where, TB - tax burden; 
$\mathrm{T}_{\mathrm{y}}$ - amount of taxes paid according to the report in the tax year;

$\mathrm{SR}_{\mathrm{y}}$ - sum of revenue from accounting documents, corresponding to the tax year period; it does not join the VAT and excises.

This technique is developed and recommended for application by the Ministry of Finance of the Russian Federation.

For example, tax burden on the industry "Water supply, water sewage, the organization of collecting and recycling, activity and elimination of pollution" during 2017 was $8.4 \%$, fiscal loading on insurance premiums was $4.8 \%$. Comparing to the industry average level of tax burden through Russia, it makes $10.8 \%$ in 2017 [5].

In Sweden there is wide experience on processing of household waste and receiving from them electric and thermal energy in respect of power- and resource-saving. $96 \%$ of household waste are utilized in total (that is one of the highest rates in the world). The population choses the new model of economy: tax benefits are offered house owners upon transition to renewables; taxes for the car owners using environmentally friendly types of fuel for the cars decrease. For such cars, free places on city parking lots are also provided. The use of biofuel, used generally for the production of heat extends. Tax regulation (reduction in taxes on "clean" cars), and government resolutions (for example, that all large gas stations are obliged to sell at least one type of biofuel) stimulates the use of the biodiesel and ethanol, replacing with that the usual types of fuel having a harmful impact on the environment.

\section{Discussion}

After introduction of the bans on deliveries to Russia of the hi-tech equipment to the Russian in the USA and the EU energy companies have to be brought out of sanctions. Restrictive measures have to be removed in case if they affect environmental safety. Such opinion was expressed by the head of the Russian Union of Industrialists and Entrepreneurs A. Shokhin. "It is necessary to use ecological aspect during discussion of extension of sanctions. For example, the ban on the use of high western technologies by the Russian energy companies is imposed. But these technologies are the guarantee of preservation of ecology. If the Russian companies work without them at the shelf, for example, in the Arctic, they will pollute the environment" [6].

The Chairman of the Commission of the Civic chamber of the Russian Federation on ecology and environmental management A. Dudareva noted that "Reform of the industry of the address with waste goes with big lag. But new facilities for processing of waste have not appear yet. We do not see that the enterprises passed to the new technologies, reducing negative impact on the environment. Those facilities, on which placement of waste is conducted, become subjects of the saved-up ecological damage and have already negative effect both on the nature, and on human health" [7].

The Head of Public council of Federal Agency for Water Resources of the Russian Federation V. Danilov-Danilyan emphasized that the creation of a uniform system of the state environmental monitoring is very relevant today.

\section{Conclusions}

Side tax benefits for ecological research and development will promote the emergence of innovations, but not fundamental opening. Taxes have to be directed directly to elimination of ecological damage, but not to try to stimulate specially innovations with their benefits. The matter of the lack of ecological innovations has to be resolved at the expense of the general innovative policy of the state. The importance of environmental problems grows all 
over the world. While the economy develops, the increase in the population the environment is under escalating pressure. While the real income grows, people want to live in environmentally friendly areas and for the wellbeing are ready to allocate funds from the income for environment protection, but it should not be boundless. Therefore at high efficiency and low costs achievement of the ecological purposes remains the main priority.

In order to make the enterprises invest in ecological innovations it is necessary to provide the following:

- transferring of the tax burden towards those sectors of economy, which activity causes the greatest damage to the surrounding environment (power, transport and agriculture);

- increase in rates of taxes and fees at household garbage;

- stimulation of ecological innovations and modernization of processes of production and rendering services, transportation of products;

- stimulation of investments into environmental protection, especially in powerintensive sectors, on transport and in agriculture by the means of taxes;

- introduction of taxes on noise from air transport and also from motor-transport;

- decrease in power consumption of transport engines, household appliances;

- investments into the development of public transport.

According to the research it is revealed, that business is engaged in ecological innovations too little in Russia. Though legislation supposes some special tax benefits for the enterprises, performing research and development, connected with the ecological innovations, there are problems. It is proved that the implementation of the technologies, developed by the "preferential" researches and development does not make much profit for the producer of innovations.

In Russia the level of introduction of ecological innovations proves the little enterprises, carrying them out. The prospects of realization of ecological innovations, are connected with the changes in the legislation, directed to the development of technical regulations and new priorities in the sphere of industrial and consumption waste treatment, as well as with participation in the development of international standards on the use and introduction of renewable energy resources, stimulation of investments into environmental protection by the means of taxes. Those enterprises, which cause huge environmental damage, ought to pay more taxes.

\section{References}

1. G.N. Semenova, Role of accounting and taxation in financial development of business 1, 23-26 (2017)

2. G.N. Semenova, Role of accounting and taxation in financial development business $\mathbf{1}$, 21-23 (2017)

3. I. Markina, A. Sharkova, M. Barna, International Journal of Entrepreneurship 22(3), 12-21 (2018)

4. M.A. Bahauovna, M.A. Bahauovna, International Journal of Applied Engineering Research 11(9), 6808-6816 (2016)

5. L.N. Nikolova, D. G. Rodionov, M.A. Bahauovna, International Journal of Economics and Financial 6(2), 246-252 (2016)

6. K. Kunanbayeva, A.Gorovoy, A. Butyrin, MATEC Web of Conferences 193, 05048 (2018)

7. O.E. De Falco, Rivista Giurdica dell'Ambiente 19(5), 643-663 (2004) 